\title{
Upper gastrointestinal pathophysiology due to mouse malaria Plasmodium berghei ANKA infection
}

\author{
Mizuho Shimada1*, Yoshie Hirose², Kazuhiko Shimizu², Daisuke S. Yamamoto' ${ }^{1}$ Eri H. Hayakawa ${ }^{1}$ and \\ Hiroyuki Matsuoka ${ }^{1}$
}

\begin{abstract}
Background: Epigastric pain, vomiting, and other gastrointestinal problems are among the most important symptoms of malaria infection as they suggest the possibility that the condition is serious. Pathophysiologies such as gastric mucosal changes and delayed gastric emptying have been reported in serious cases of malaria infection. However, it is unclear whether or not pathophysiological involvement of the upper gastrointestinal tract occurs in Plasmodium berghei ANKA (PbA)-infected mice.

Methods: PbA-infective Anopheles mosquitoes were used to infect mice via the natural route of infection. Fifteen $\mathrm{PbA}-\mathrm{C} 57 \mathrm{BL} / 6$ mice were used as a cerebral malaria model and the same numbers of PbA-BALB/C mice were used as a cerebral malaria-resistant model, and then we investigated the pathophysiological involvement of the stomach and small intestine.

Results: On day 8 post infection, six PbA-C57BL/6 mice showed cerebral malaria and nine others had uncomplicated infection. All the PbA-C57BL/6 mice on that same day showed severe weight loss with multiple, red gastric patches and changes to the course of the small intestine with villus goblet cell enlargement. In addition, cerebral malaria cases showed gastric gas retention with submucosal edema and small intestinal shortening. In $\mathrm{PbA}-\mathrm{BALB} / \mathrm{c}$ mice, overextension of the stomach and gas retention were evident from week 2 after $\mathrm{PbA}$ infection, as well as changes to the course of the small intestine and mesenteric thinning with fragility.
\end{abstract}

Conclusions: We described the upper gastrointestinal pathophysiology representing new findings directly linked to malarial severity and subsequent death in PbA-infected mice as a mouse model of malaria infection.

Keywords: Plasmodium berghei ANKA, Anopheles stephensi, Stomach, Small intestine, Gastric red patches, Submucosal edema, Goblet cell

\section{Background}

Malaria, one of the most important mosquito-borne parasitic diseases, caused 219 million cases and 435,000 related deaths in 2017 [1]. Malarial parasites that can infect humans are classified into five species, with the most lethal among humans being Plasmodium falciparum. Malaria infection begins with the non-specific symptoms of acute high fever and severe headache.

\footnotetext{
* Correspondence: m.shimada@jichi.ac.jp

${ }^{1}$ Division of Medical Zoology, Department of Infection and Immunity, Jichi Medical University, 3311-1, Yakushiji, Shimotsuke City, Tochigi 329-0498, Japan

Full list of author information is available at the end of the article
}

When it reaches the severe stage, it causes not only cerebral malaria due to sequestration of parasites in the brain [2] and brain edema [3] but also multiple organ dysfunction, including pulmonary edema and renal failure [4]. P. falciparum infection produces significantly more upper gastrointestinal symptoms than does $P$. vivax infection [5], and its pathophysiology may include delayed gastric emptying time, changes in the gastric mucosa, and increased gastrointestinal permeability [6-8]. Reduced fluid and food intake due to persistent upper gastrointestinal symptoms, such as epigastric pain and vomiting, may also lead to dehydration and electrolyte imbalance, which adversely affect the course of malaria infection. However,

(C) The Author(s). 2019 Open Access This article is distributed under the terms of the Creative Commons Attribution 4.0 International License (http://creativecommons.org/licenses/by/4.0/), which permits unrestricted use, distribution, and 
few studies have addressed the detailed course of the upper gastrointestinal pathophysiology of malaria infection in humans, and none has described the pathophysiology of the upper gastrointestinal tract, including the stomach, in mouse models of malaria.

Mice infected with $P$. berghei ANKA (PbA) [9] are widely used as a mouse model of malaria infection. PbA-infected C57BL/6 (PbA-C57BL/6) mice are the best-known cerebral malaria models $[10,11]$, and diagnostic imaging has revealed the presence of ischemic brain edema [12]. Intestinal floral changes and intestinal shortening have been reported as intestinal pathologies of $\mathrm{PbA}-\mathrm{C} 57 \mathrm{BL} / 6$ mice with cerebral symptoms [13]; however, in that study, the $\mathrm{PbA}$ infection route was via the infusion of infected red blood cells (RBCs) into the peritoneal cavity. In humans, inflammation of the peritoneal cavity generally causes ileus due to impaired intestinal motility, and introducing malaria-infected RBCs into the mouse peritoneal cavity may also cause intraperitoneal inflammation and affect peristalsis. In the current study, we therefore used PbA-infective Anopheles mosquitoes to produce $\mathrm{PbA}$-infected mice, in order to investigate the pathophysiology of the stomach and small intestine in a more natural mouse model of malaria [14]. C57BL/6 mice were used as a cerebral malaria model, and BALB/c mice as a cerebral malaria-resistant model. This is the first study to describe the upper gastrointestinal pathophysiology of PbA-infected mice.

\section{Results}

We evaluated changes in peripheral parasitemia of $\mathrm{PbA}$-infected mice. Among $15 \mathrm{PbA}-\mathrm{C} 57 \mathrm{BL} / 6$ mice, the average parasitemia exceeded $1 \%$ on day $5(1.2 \% \pm 0.9 \%)$. Six PbA-C57BL/6 mice developed cerebral malaria on day 8 (four cases of convulsions and two cases of lower limb paresis), and nine other mice had uncomplicated malaria. The mice were next retrospectively divided into two groups depending on whether they showed cerebral malaria on day 8 (group A) or uncomplicated malaria on that same day (group B). In group A, peripheral parasitemia was $4.0 \pm 0.7 \%$ on day $6,5.7 \pm 2.1 \%$ on day 7 , and $6.1 \% \pm 1.8 \%$ on day 8 , while in group B, peripheral parasitemia was $3.5 \pm 1.3 \%$ on day $6,4.0 \pm 0.6$ on day 7 , and $4.3 \pm 1.5 \%$ on day 8 ( $p=0.056$, Student's $t$ test). In $\mathrm{PbA}-\mathrm{BALB} / \mathrm{c}$ mice, the average parasitemia exceeded $1 \%$ on day $6(1.3 \% \pm 1.0 \%)$ and $3.7 \% \pm 0.8 \%$ on day 8 , after which it rapidly increased to $32.5 \% \pm 9.0 \%$ on day 12 , $43.2 \% \pm 8.1 \%$ on day 13 , and $57.2 \% \pm 11.8 \%$ on day 15 (Fig. 1). The level of peripheral parasitemia did not explain the difference between groups $A$ and $B$ in $\mathrm{PbA}-\mathrm{C} 57 \mathrm{BL} / 6$ mice.

We next investigated changes in the weight and food intake of PbA-infected mice. The weight of PbA-C57BL/ 6 mice started to decrease significantly on day 6 post infection and was the lowest on day 8 both in groups $\mathrm{A}$ $(-0.08 \pm 0.05 \%$ decrease $)$ and B $(-0.08 \pm 0.02 \%$ decrease), when there was a highly significant difference between the $\mathrm{PbA}$-infected group and the uninfected control group ( $p=9.27 \times 10^{-11}$, Student's $t$ test) (Fig. 2a). The weight of the $\mathrm{PbA}-\mathrm{BALB} / \mathrm{c}$ mice started to show a significant decrease on day 13 post infection $\left(p=3.55 \times 10^{-7}\right.$, Student's $t$ test $)$, and this decline was subsequently maintained $(-0.07 \pm 0.04 \%$ decrease on day 15), with a highly significant difference between this group and the uninfected control group $\left(p=1.32 \times 10^{-9}\right.$, Student's $t$ test) (Fig. 2b). In terms of changes in weight and food intake, PbA-C57BL/6 mice (both groups $\mathrm{A}$ and B) virtually stopped eating on days 6,7 , and 8 post infection, with food intakes of $2.7 \pm 0.5 \mathrm{~g}, 1.1 \pm 0.5 \mathrm{~g}$, and $0.2 \pm$ $0.2 \mathrm{~g}$, respectively (Fig. 2c), consistent with their weight loss. Food intake by PbA-BALB/c mice started to show a significant decrease on day 12 post infection $(1.0 \pm 0.1 \mathrm{~g})$ and was subsequently maintained at $1.0 \pm 0.4 \mathrm{~g}$ until day 15 (Fig. 2d), consistent with their sustained weight loss.

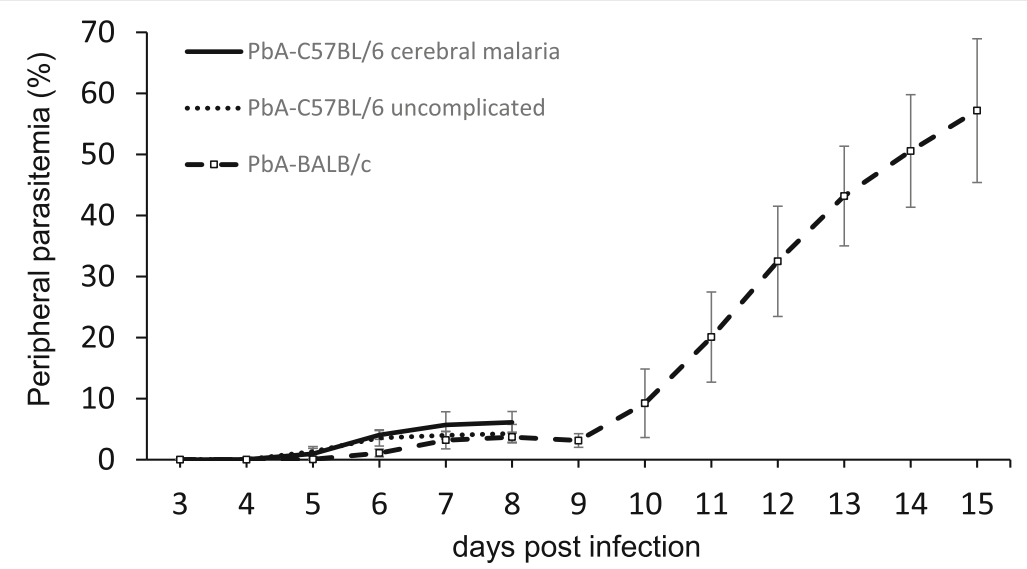

Fig. 1 Peripheral parasitemia. Parasitemia of PbA-C57BL/6 mice with cerebral malaria $(n=6)$ and uncomplicated malaria $(n=9)$ from day 3 until day 8 post infection is shown with SD. Parasitemia of $\mathrm{PbA}-\mathrm{BALB} / \mathrm{c}$ mice from day 3 until day 15 post infection is shown with SD 


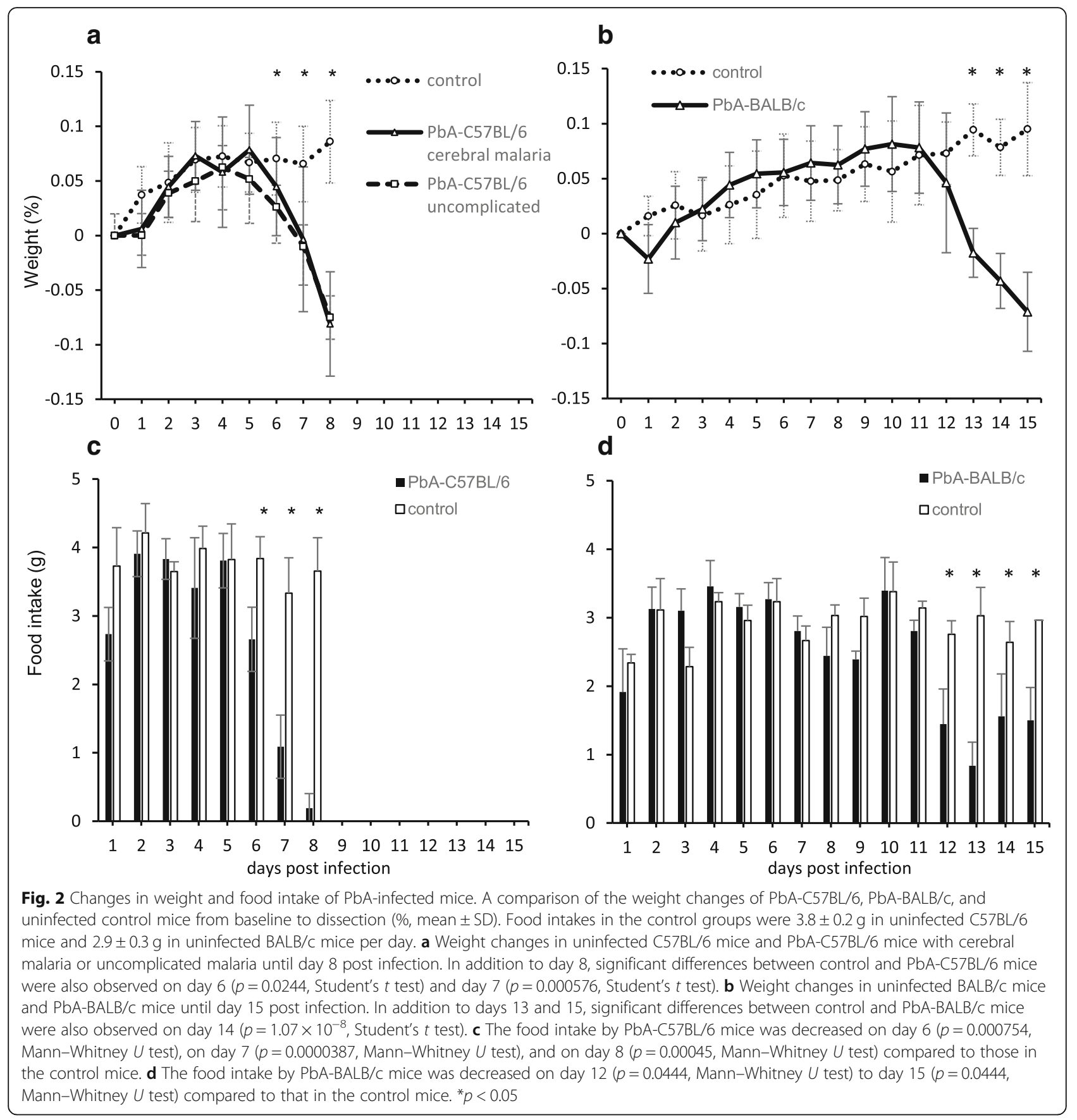

PbA-infected mice thus exhibited diminished food intake and significant weight loss at specific periods after infection, depending on the strain concerned.

We investigated the gross pathology of the gastrointestinal tract of PbA-infected mice. Six among 15 PbA-C57BL/6 mice showed cerebral malaria on day 8 (group A), and thus, all the mice in both groups $\mathrm{A}$ and $\mathrm{B}$ were dissected as with the control C57BL/6 mice when the group A mice presented cerebral symptoms. Compared with uninfected C57BL/6 mice (Fig. 3a, b), the gross pathology of group A and B mice revealed changes to the course of the small intestine (Fig. 3c). The upper small intestine was edematous, and there was reduced gastrointestinal content overall (Fig. 3d). In group $\mathrm{A}$, the skulls were opened to remove the brain and examine the pathology. The brain was edematous, while bleeding or sequestration of the parasite in the bloodstream was not observed. Peritoneal examination of $\mathrm{PbA}-\mathrm{BALB} / \mathrm{c}$ mice on day 12 (six mice), on day 13 (three mice), or on day 15 (six mice) revealed not only 


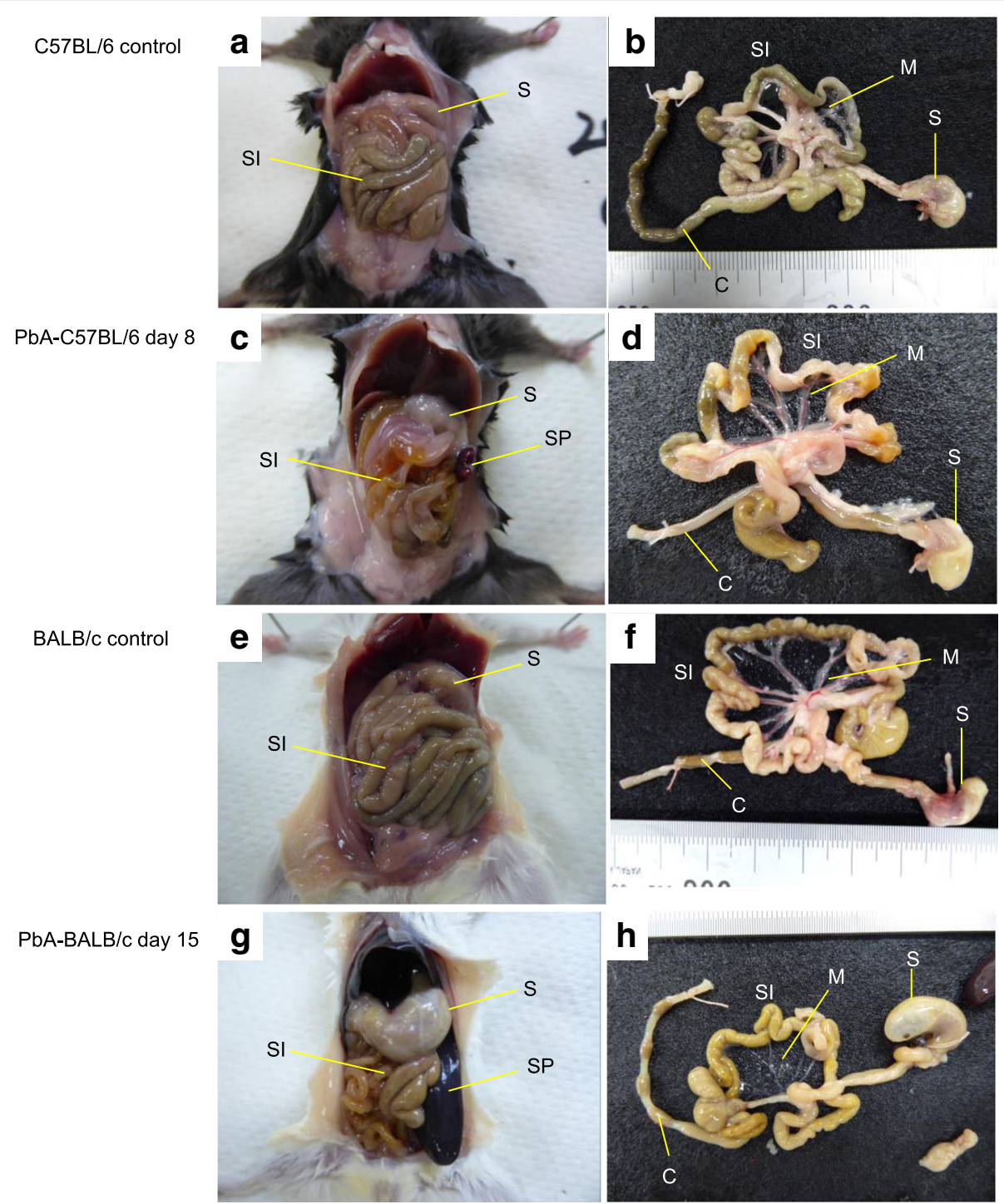

Fig. 3 Mouse abdominal gross pathology. A PbA-C57BL/6 mouse on day 8 and a PbA-BALB/c mouse on day 15 are shown with uninfected controls. a Macroscopic examination of the peritoneal cavity of an uninfected C57BL/6 mouse, showing the stomach and small intestine. $\mathbf{b}$ The stomach, small intestine, mesentery, and colon after removal from the mouse shown in a, c Macroscopic examination of the peritoneal cavity of a PbA-C57BL/6 mouse revealed a change in the course of the small intestine, and the spleen started to enlarge. $\mathbf{d}$ The gastrointestinal tract after removal from the mouse shown in $\mathbf{c}$, with an edematous small intestine with reduced intestinal content and a colon containing only a small amount of retained faces. e Macroscopic examination of the peritoneal cavity of an uninfected BALB/C mouse. $\mathbf{f}$ The gastrointestinal tract after removal from the mouse shown in $\mathbf{e}, \mathbf{g}$ Macroscopic observation of the peritoneal cavity of a PbA-BALB/c mouse revealed splenomegaly, dilatation of the stomach, and a change in the course of the small intestine. $\mathbf{h}$ The gastrointestinal tract after removal from the mouse shown in g, with a thinned, fragile mesentery. C colon, M mesentery, S stomach, SI small intestine, SP spleen

splenomegaly, which was prominent on day $12(3.2 \pm 0.2$ $\mathrm{cm})$ and progressed to day $15(3.4 \pm 0.1 \mathrm{~cm})(p=0.0261$, Student's $t$ test), and changes in the course of the small intestine but also gastric dilatation with much content inside. On day 15, the stomach dilatation was the most severe with excessive content and accumulated gas (Fig. 3g, h) compared with that observed in uninfected mice (Fig. 3e, f). The removed gastrointestinal tract of $\mathrm{PbA}-\mathrm{BALB} / \mathrm{c}$ mice on day 15 had an especially thin, fragile mesentery (Fig. 3h). The stomach and small intestinal involvement thus comprised changes in the course of the small intestine in both strains of $\mathrm{PbA}$-infected mice. The gastrointestinal contents were reduced in all $\mathrm{PbA}-\mathrm{C} 57 \mathrm{BL} / 6$ mice on day 8 , while stomach contents caused gastric dilatation in all $\mathrm{PbA}-\mathrm{BALB} / \mathrm{c}$ mice after day 12 .

In PbA-infected mice, gastric gas retention was assessed by whether or not the stomach floated in saline. The absence of gas in the stomach was proved in both strains using 10 uninfected mice as controls. The 
stomachs of six $\mathrm{PbA}-\mathrm{C} 57 \mathrm{BL} / 6$ mice with cerebral malaria (group A) floated (Fig. 4b), but those of uninfected C57BL/6 mice (Fig. 4a) and nine uncomplicated $\mathrm{PbA}-\mathrm{C} 57 \mathrm{BL} / 6$ mice on that day (group B) did not. The stomachs of uninfected BALB/C mice (Fig 4c) and those of six $\mathrm{PbA}-\mathrm{BALB} / \mathrm{c}$ mice dissected on day 12 did not float, but mild floating was seen on day 13. Six $\mathrm{PbA}-\mathrm{BALB} / \mathrm{c}$ mice on day 15 showed severe gastric gas retention with the stomachs floating high enough to break the surface (Fig. 4d).

We then investigated the small intestine length in $\mathrm{PbA}$-infected mice by comparing the length of the small intestine in uninfected C57BL/6 mice and PbA-C57BL/6 mice in groups A (cerebral malaria) and B (uncomplicated malaria) on day 8 . We found that the small intestine was only shorter in PbA-C57BL/6 mice of group A that exhibited gastric gas retention $(p=0.00134$, Kruskal-Wallis, Steel-Dwass) (Fig. 5a). A comparison of the length of the small intestine in uninfected BALB/c mice and $\mathrm{PbA}-\mathrm{BALB} / \mathrm{c}$ mice with or without floating stomachs (six mice each on days 15 and 12) found no significant differences among any of the three groups $(p=$ 0.33, Kruskal-Wallis) (Fig. 5b).

We then evaluated the pathology of the stomach and small intestine in PbA-infected mice. Compared with uninfected mice (Fig. 6a), there were multiple red patches of gastric mucosa in both group A (cerebral malaria) and B (uncomplicated malaria) PbA-C57BL/6 mice on day 8 (Fig. 6c). Compared with the histological specimens of uninfected mice (Fig. 6b), those of $\mathrm{PbA}-\mathrm{C} 57 \mathrm{BL} / 6$ mice in group $\mathrm{A}$ displayed gastric sub-mucosal edema (Fig. 6d). In PbA-BALB/c mice, the whole stomach was distended severely on day 15 (Fig. 6e), and histopathological specimens showed severe thinning of both the mucosa and muscularis (Fig. 6f).

In the small intestine of PbA-C57BL/6 mice in both groups $\mathrm{A}$ and $\mathrm{B}$, the goblet cells in villi were clearly enlarged (Fig. 7b) compared with those of uninfected C57BL/6 mice (Fig. 7a), while the goblet cells in villi of $\mathrm{PbA}-\mathrm{BALB} / \mathrm{c}$ mice were not enlarged (Fig. $7 \mathrm{~d}$ ) compared with those of uninfected BALB/c mice (Fig. $7 \mathrm{c}$ ).

A summary of the upper gastrointestinal pathophysiology observed in PbA-infected mice is presented in Table 1.

\section{Discussion}

We evaluated the upper gastrointestinal pathophysiology in PbA-infected mice. Overall, both $\mathrm{PbA}-\mathrm{C} 57 \mathrm{BL} / 6$ and $\mathrm{PbA}-\mathrm{BALB} / \mathrm{c}$ mice exhibited gastric gas retention and changes to the course of the small intestine at the time cerebral malaria developed or after a certain period post infection, but small intestinal shortening was only evident in $\mathrm{PbA}-\mathrm{C} 57 \mathrm{BL} / 6$ mice with cerebral malaria. In terms of pathology, $\mathrm{PbA}-\mathrm{C} 57 \mathrm{BL} / 6$ mice exhibited red patches in the gastric mucosa and roundly enlarged villus goblet cells in the small intestine, while the group with cerebral malaria also exhibited gastric submucosal edema. $\mathrm{PbA}-\mathrm{BALB} / \mathrm{c}$ mice developed severe gastric dilatation as well as mesenteric thinning and fragility.

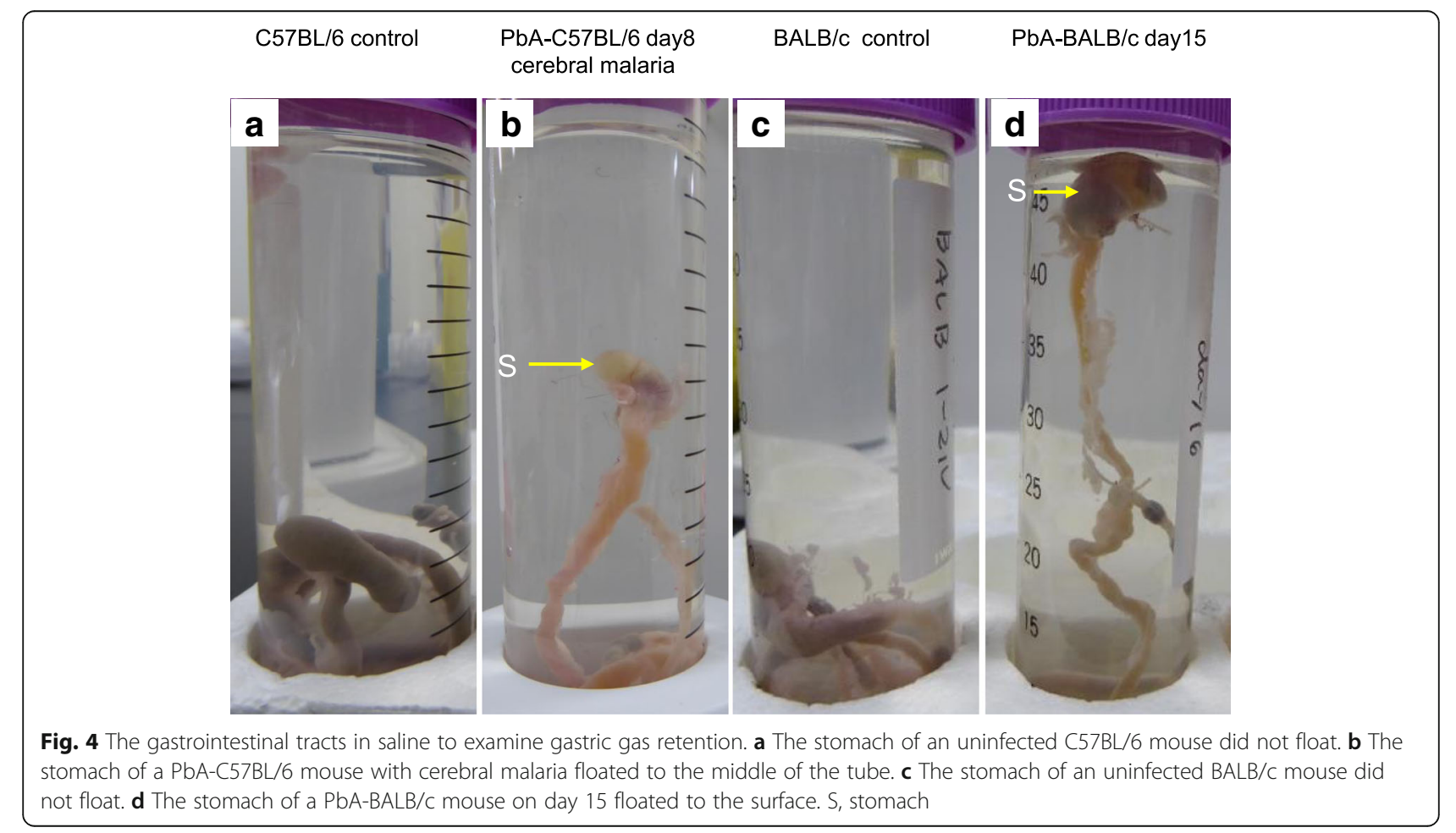




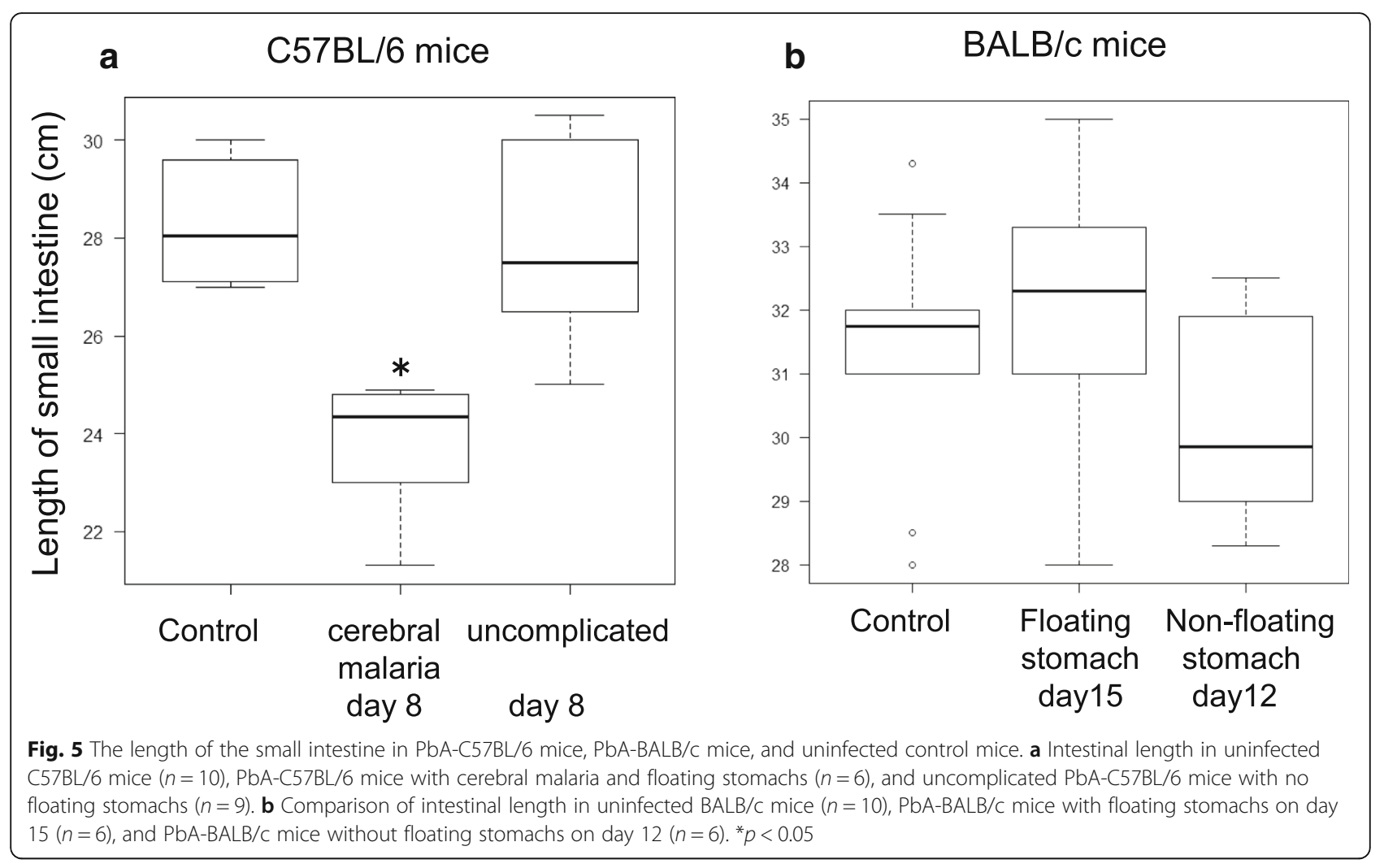

Cerebral malaria was found consistently in 6/15 $\mathrm{PbA}-\mathrm{C} 57 \mathrm{BL} / 6$ mice on day 8 post infection via infective mosquitoes, a finding at odds with reports that cerebral malaria appeared between 6 days and 2 weeks after $\mathrm{PbA}$ peritoneal infection $[10,13,15]$. Although malaria infection via infective mosquito bite does not deliver a consistent number of sporozoites, intravenous infection with varying concentrations of sporozoites does not result in any difference in the prepatent period [16], and our investigation of the effect of $\mathrm{PbA}$ on intestinal function suggests that infection established by $\mathrm{PbA}$-infective mosquitoes has the advantage of not entailing the risk of peritoneal inflammation. In the severe stage of malaria in $\mathrm{PbA}-\mathrm{BALB} / \mathrm{c}$ mice, high parasitemia is known to be completed around day 15 with severe anemia [15], leading to death in 3 weeks under an extremely high parasitemia of over $60 \%$ [13]. In this study, we found for the first time that at the point at which parasitemia rapidly increased in PbA-BALB/c mice, significant weight loss, severe gastric dilatation with gas accumulation, and mesenteric thinning with fragility occurred, and we consider that these findings are also important factors contributing to mortality.

The weight of $\mathrm{PbA}-\mathrm{C} 57 \mathrm{BL} / 6$ mice infected via $\mathrm{PbA}$-infective mosquitoes did not start to decline immediately after infection, as is the case when $\mathrm{PbA}$ is delivered by peritoneal infusion [15]. Instead, weight rapidly decreased from day 6 post infection, reaching a significant reduction in food intake and weight loss by day 8. The weight of $\mathrm{PbA}-\mathrm{BALB} / \mathrm{c}$ mice exhibited a sustained decrease consistent with decreased food intake from day 12 post infection, but even on day 15 , their food intake remained at around half of that of uninfected mice, consistent with the large amount of food residue and serious gastric dilatation seen in dissected $\mathrm{PbA}-\mathrm{BALB} / \mathrm{c}$ mice. Our results showed that mice infected with $\mathrm{PbA}$ via PbA-infective mosquitoes exhibited diminished food intake and concomitant weight loss at specific periods after infection, depending on the strain concerned.

Disease-specific gastric gas retention was evident in both strains of PbA-infected mice used in this study, but in uninfected mice, gastric contents consisting of swallowed food and air were transported to the lower gastrointestinal tract by peristaltic movements of the intestine with no excessive accumulation in the stomach. When humans develop upper gastrointestinal gas retention due to intestinal ileus, the intragastric pressure is released via a gastric tube while the underlying disease is treated. In this study, which did not include either disease treatment or intragastric decompression, gas was irreversibly retained in the stomach as the disease progressed. Studies of gastric gas retention in other species include reports of inflammatory diseases and multiple organ dysfunction in dogs [17], and this gastric gas retention was reportedly caused by the reflux of intestinal gas generated by rapidly proliferating intestinal bacteria rather 


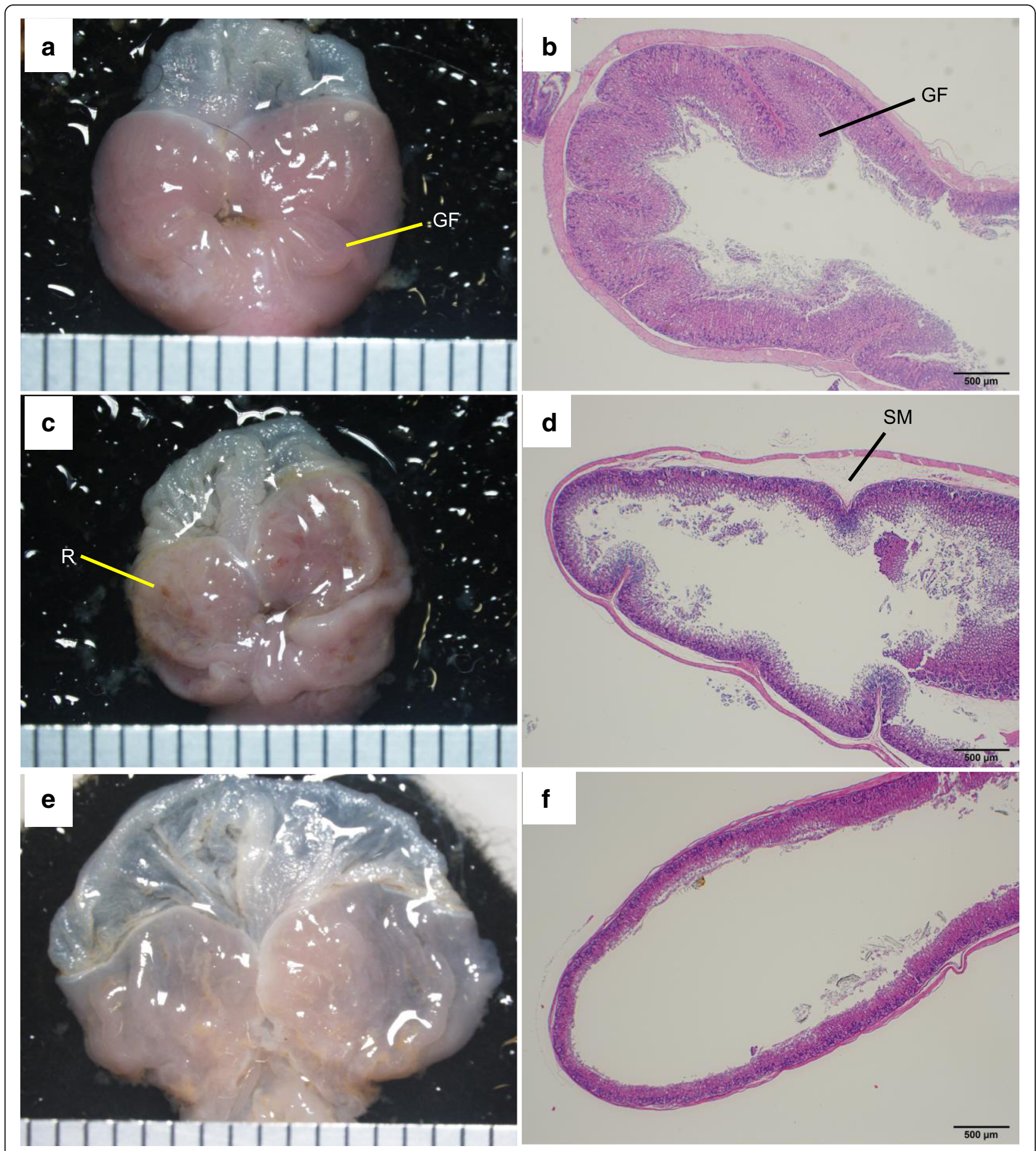

Fig. 6 Pathology of the stomach. A PbA-C57BL/6 mouse with cerebral malaria on day 8 and a PbA-BALB/C mouse on day 15 are shown with uninfected C57BL/6 mouse. a Gastric mucosa of an uninfected C57BL/6 mouse, showing the gastric fold. $\mathbf{b}$ Gastric mucosa of the mouse shown in a stained with H\&E, showing the gastric fold. c Multiple red patches on the gastric mucosa of a PbA-C57BL/6 mouse. $\mathbf{d}$ H\&E-stained gastric mucosa of

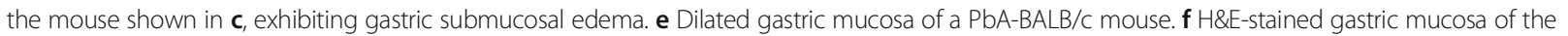
mouse shown in $\mathbf{e}$, showing thinning of the mucosa and the muscularis propria. GF gastric fold, R red patches, SM submucosal edema

than by swallowing air [18]. In mouse malaria, changes in intestinal flora have also been reported in cerebral malaria of $\mathrm{PbA}-\mathrm{C} 57 \mathrm{BL} / 6$ mice [13], but ours is the first study of gastric gas retention in multiple strains of PbA-infected mice. We observed gastric gas retention together with a large volume of food residue in $\mathrm{PbA}-\mathrm{BALB} / \mathrm{c}$ mice. In 



Fig. 7 Histopathology of the small intestine. H\&E-stained small intestinal villi of a PbA-C57BL/6 mouse on day 8 and a PbA-BALB/C mouse on day 15 are shown with uninfected controls. a The villus of a control C57BL/6 mouse. $\mathbf{b}$ Enlarged villus goblet cells of a PbA-C57BL/6 mouse. c The villus of a control BALB/C mouse. $\mathbf{d}$ Villus goblet cells of a PbA-BALB/C mouse

general, if the amount of gastric content exceeds a certain volume, this causes increased pressure in the pyloric area. This makes the difficulty in eliminating gastric contents irreversible, and a number of cases of fatal gastric distension in humans have been reported $[19,20]$. In PbA-BALB/c mice, this is not inconsistent with the malaria-related deaths observed in $\mathrm{PbA}$ infection $[13,15]$. Thus, the gastric gas retention with a large volume of food residue seen in $\mathrm{PbA}-\mathrm{BALB} / \mathrm{c}$ mice in this study is a new finding that is not inconsistent with the irreversible process leading to death.
When gastric gas retention was present, $\mathrm{PbA}-\mathrm{C} 57 \mathrm{BL} / 6$ mice with cerebral malaria also exhibited significant shortening of the small intestine, and this finding has also been reported in $\mathrm{PbA}-\mathrm{C} 57 \mathrm{BL} / 6$ mice with cerebral malaria induced by $\mathrm{PbA}$ peritoneal infection [13]. Small intestinal shortening is thus evident in $\mathrm{PbA}-\mathrm{C} 57 \mathrm{BL} / 6$ mice with cerebral malaria irrespective of the $\mathrm{PbA}$ infection route. However, we did not observe any significant inflammatory cell infiltration of the villous capillary vessels in infected individuals with shortened small

Table 1 The upper gastrointestinal pathophysiology

\begin{tabular}{|c|c|c|c|c|c|c|c|}
\hline \multirow[b]{2}{*}{ Mouse model } & \multicolumn{4}{|l|}{ Stomach } & \multicolumn{3}{|l|}{ Small intestine } \\
\hline & Gas retention & Dilatation & $\begin{array}{l}\text { Mucosal red } \\
\text { patches }\end{array}$ & $\begin{array}{l}\text { Submucosal } \\
\text { edema }\end{array}$ & Course change & Shortening & $\begin{array}{l}\text { Goblet cell } \\
\text { enlargement }\end{array}$ \\
\hline PbA-C57BL/6 cerebral malaria day $8(n=6)$ & ++ & - & ++ & + & ++ & + & + \\
\hline PbA-C57BL/6 uncomplicated malaria day $8(n=9)$ & - & - & + & - & ++ & - & + \\
\hline $\mathrm{PbA}-\mathrm{BALB} / \mathrm{c}$ day $12(n=6)$ & - & ++ & - & - & +++ & - & - \\
\hline $\mathrm{PbA}-\mathrm{BALB} / \mathrm{c}$ day $15(n=6)$ & +++ & +++ & - & - & +++ & - & - \\
\hline
\end{tabular}


intestines, and there were no histopathological findings that could explain the shortening seen on day 8 post infection. Intestinal length is generally considered to be influenced by smooth muscle function, and if the muscularis propria were to go into spasm in PbA-C57BL/6 mice, this might shorten the small intestine in a short period. Moreover, small intestine shortening occurred simultaneously with cerebral malaria, showing brain edema in $\mathrm{PbA}-\mathrm{C} 57 \mathrm{BL} / 6$ mice without bleeding or sequestration in the vessels. If small intestinal smooth muscle spasm is regarded as a sign of systemic smooth muscle spasm, it would not be inconsistent to view the cerebral malaria and small intestinal shortening as aspects of systemic smooth muscle spasm, with different symptoms appearing simultaneously at different sites.

In terms of gastric mucosal pathology, on day 8 post infection, there were multiple red patches in the gastric mucosa of $\mathrm{PbA}-\mathrm{C} 57 \mathrm{BL} / 6$ mice, suggesting changes to mucosal perfusion in these areas corresponding to acute gastric mucosal lesions (AGMLs) in humans. In the $\mathrm{PbA}-\mathrm{C} 57 \mathrm{BL} / 6$ mice that exhibited this finding, the appearance of gastric mucosal lesions may have caused the sudden decrease in food intake, causing weight loss. This gastric sub-mucosal edema was first shown in $\mathrm{PbA}-\mathrm{C} 57 \mathrm{BL} / 6$ mice with cerebral malaria, and in general, submucosal edema has been reported to appear in association with the severity of AGMLs [21, 22], which was concordant with our observation that edema appeared only in the cases of cerebral malaria in which gastric mucosal patches were more severe. About the involvement of the small intestine in PbA-infected mice, this is the first evidence of goblet cell enlargement in the small intestinal villi of $\mathrm{PbA}-\mathrm{C} 57 \mathrm{BL} / 6$ mice whether or not cerebral malaria was present, but this was not clearly evident in PbA-BALB/c mice. Goblet cells are known to produce mucin to protect against pathogens [23], and our results suggest differences between the intestinal immunity of $\mathrm{PbA}-\mathrm{C} 57 \mathrm{BL} / 6$ mice.

In this study, $\mathrm{PbA}$ infection was revealed as one of the causes of the pathophysiological involvement of the stomach and small intestine in malaria. The emergence of lesions in these organs seems to be related to the sharing of arteries, veins, and lymphatic systems with the spleen where PbA-infected RBCs cause continuous reactions to induce splenomegaly, but it is difficult to proof this at this stage.

\section{Conclusions}

While $\mathrm{PbA}-\mathrm{C} 57 \mathrm{BL} / 6$ mice tend to exhibit primarily cerebral malaria, the simultaneous occurrence of pathophysiological changes in the stomach and small intestine, including changes to the course of the small intestine, small intestinal shortening with villus goblet cell enlargement, and gastric mucosal changes, represents new findings directly linked to malarial severity. We also demonstrated for the first time that the previously neglected upper gastrointestinal pathophysiology of $\mathrm{PbA}-\mathrm{BALB} / \mathrm{c}$ mice plays an important role in the irreversible severity of malaria and subsequent death.

\section{Methods \\ Animals}

Seven-week-old female mice (C57BL/6NCr and BALB/ $\mathrm{cCr}$ ) were purchased from Japan SLC. Inc. (Hamamatsu, Japan). Mice had free access to drinking water and feed purchased from CLEA Japan Inc. (CE-2; Tokyo, Japan) and were housed at a temperature of $23^{\circ} \mathrm{C} \pm 1{ }^{\circ} \mathrm{C}$ under a 12-h light-dark cycle. Fifteen mice of each strain were infected, while 10 mice were used as uninfected controls.

\section{Parasites and infection through infective mosquitoes}

The rodent malaria parasite Plasmodium berghei ANKA strain clone 2.34 [24], which had been passaged in our laboratory, was used. Anopheles stephensi SDA 500 strain was used as a malaria transmission vector mosquito.

Infective mosquitoes were prepared in accordance with previously described procedures [25] and housed at $21^{\circ} \mathrm{C} \pm 1{ }^{\circ} \mathrm{C}$ and $80 \%$ humidity under a 12 -h light-dark cycle with free access to $5 \%$ fructose with $0.05 \% p$-aminobenzoic acid. Fourteen days later, 10 mosquitoes were dissected to observe the midgut. If eight or more mosquitoes developed malaria oocysts on the midgut, we used the mosquito batch for the next experiment. Eight mosquitoes from a batch were placed in a cage $(16 \times 26 \times 26 \mathrm{~cm})$ and fasted for $6 \mathrm{~h}$. Then, a mouse was placed in a cage with a wire mesh and mosquitoes were allowed to bite for $4 \mathrm{~min}$ to complete malaria infection.

\section{Physical findings and anatomy}

Peripheral parasitemia was measured by blood smears every day between day 3 post infection and the date of dissection. Approximately $2 \mu \mathrm{L}$ of blood was collected from each infected mouse by making a small incision in the tail with a sterile scalpel. The blood smears were stained with Giemsa's azur-eosin-methylene blue solution and examined under a microscope (Merck KGaA, Darmstadt, Germany), and the numbers of parasites per 3,000 RBCs were counted.

$\mathrm{PbA}-\mathrm{C} 57 \mathrm{BL} / 6$ mice, $\mathrm{PbA}-\mathrm{BALB} / \mathrm{c}$ mice, and uninfected mice were weighed every day from baseline to the date of dissection, and the weight on each day was divided by the weight at baseline to calculate percentage weight (\%). The weights of PbA-C57BL/6 mice and uninfected $\mathrm{C} 57 \mathrm{BL} / 6$ mice were measured until day 8 , and the weights of $\mathrm{PbA}-\mathrm{BALB} / \mathrm{c}$ mice were measured until day 15 . The weights of uninfected $B A L B / c$ mice were also measured until day 15 . PbA-infected mice were kept in cages containing three mice each, and uninfected 
mice in cages containing three or four mice each. The amount of food in each cage was weighed, and the amount eaten per cage was defined as the decrease in food weight compared with that on the previous day. The daily amount eaten per mouse was estimated by dividing the amount eaten per cage by the number of mice in the cage. The cages of PbA-BALB/c mice dissected on days 12 and 13 were randomly selected.

Cerebral malaria was defined as the post-infection appearance of convulsions or paresis. All the PbA-C57BL/ 6 mice $(n=15)$, including the uninfected mice $(n=10)$, were dissected on the first day when cerebral malaria was detected in any of the mice. Six among 15 $\mathrm{PbA}-\mathrm{C} 57 \mathrm{BL} / 6$ mice showed cerebral malaria on day 8 post infection (group A) and were dissected under cerebral symptoms before death; at the same time, 9 mice with uncomplicated malaria on day 8 (group B) and 10 uninfected mice were also dissected on the same day. In group A, the skull was opened, and the pathology of the brain was observed. PbA-BALB/c mice were dissected over several days during the weight loss period, with dissection carried out on day $12(n=6)$, day $13(n=3)$, and day $15(n=6)$ post infection, and 10 uninfected mice were also dissected on the same day. Prior to dissection, each mouse was euthanized with carbon dioxide, after which all the blood was collected by cardiac puncture. The abdomen was then opened, the esophagus and the distal end of the colon were ligated, and the entire gastrointestinal tract was removed. The mesentery was dissected and removed en bloc with the gastrointestinal tract, and the small intestinal length and the long diameter of the spleen were measured in centimeters.

Upper gastrointestinal dysfunction was evaluated in terms of the local presence of stomach gas in the ligated and removed gastrointestinal tract. The absence of gas in the stomach was evaluated in both strains using 10 uninfected mice. The gastrointestinal tract was placed in a 50-mL centrifuge tube (Asahi Glass Co., Ltd., Japan) containing physiological saline, and gastric gas retention was assessed in terms of whether the stomach floated.

The gastrointestinal tract was then removed from the saline, an incision was made in the major curvature of the stomach, and the gastric contents were removed by rinsing with saline. After fixation with $10 \%$ formalin solution, the organs were embedded in paraffin, cut into $2-\mu \mathrm{m}$-thick sections, and then stained with hematoxylin and eosin (H\&E).

\section{Microscopic observations}

Stereoscopic observations were conducted with an Olympus SZX7 scope (Olympus, Tokyo, Japan), and photographs were taken with a DP73 camera (Olympus). Histopathological observations were conducted using a BX-63 microscope (Olympus), and photographs were taken with a DP72 camera (Olympus).

\section{Statistical analysis}

Weight (in grams), peripheral parasitemia (\%), and the long diameter of the spleen (in centimeters) in the two groups of mice were analyzed by Student's $t$ test. The amount of food intake was analyzed by the Mann-Whitney $U$ test, and length of the small intestines (in centimeters) in the three groups of mice was analyzed by the Kruskal-Wallis test and Steel-Dwass test using EZR [26]. A $p$ value less than 0.05 was considered significant.

\section{Abbreviations \\ $\mathrm{PbA}$ : Plasmodium berghei ANKA}

\section{Acknowledgements}

We thank Hirota Surgical Pathology Institute Inc. for producing

histopathological specimens and Dr. Satoru Komatsumoto, Director of

Ashikaga Red Cross Hospital, for cooperation in this research collaboration.

\section{Funding}

This study was supported by the course research fee of Jichi Medical University.

\section{Availability of data and materials}

All data generated and analyzed during this study are included in the published article.

\section{Authors' contributions}

MS, YH, and KS made substantial contributions to the conception and design, acquisition of data, and analysis and interpretation of data. MS, DSY, $\mathrm{EHH}$, and $\mathrm{HM}$ produced the final draft of the paper. All authors made a substantial, direct, and intellectual contribution to the work. All authors read and approved the final manuscript.

\section{Ethics approval and consent to participate}

Animal experiments were performed after receiving approval from the Institutional Animal Experiment Committee of the Jichi Medical University (17063-01), in accordance with the Institutional Regulations for Animal Experiments and Fundamental Guidelines for the Proper Conduct of Animal Experiments and Related Activities in Academic Research Institutions under the jurisdiction of the Ministry of Education, Culture, Sports, Science and Technology.

Consent for publication

Not applicable.

\section{Competing interests}

The authors declare that they have no competing interests.

\section{Publisher's Note}

Springer Nature remains neutral with regard to jurisdictional claims in published maps and institutional affiliations.

\section{Author details}

'Division of Medical Zoology, Department of Infection and Immunity, Jichi Medical University, 3311-1, Yakushiji, Shimotsuke City, Tochigi 329-0498, Japan. ${ }^{2}$ Department of Pathology, Ashikaga Red Cross Hospital, 284-1, Yobe-cho, Ashikaga City, Tochigi 326-0843, Japan.

Received: 31 December 2018 Accepted: 20 February 2019 Published online: 04 March 2019

\section{References}

1. World Health Organization. World malaria report. Geneva: WHO; 2018.

2. Milner DA Jr, Valim C, Luo R, Playforth KB, Kamiza S, Molyneux ME, et al. Supraorbital postmortem brain sampling for definitive quantitative confirmation of cerebral sequestration of Plasmodium falciparum parasites. J Infect Dis. 2012;205:1601-6.

3. Seydel KB, Kampondeni SD, Valim C, Potchen MJ, Milner DA, Muwalo FW, et al. Brain swelling and death in children with cerebral malaria. New Engl J Med. 2015;372:1126-37. 
4. Herbert F, Tchitchek N, Bansal D, Jacques J, Pathak S, Bécavin C, et al. Evidence of IL-17, IP-10, and IL-10 involvement in multiple-organ dysfunction and IL-17 pathway in acute renal failure associated to Plasmodium falciparum malaria. J Transl Med. 2015;13:369.

5. Imtiaz S, Drohlia MF, Nasir K, Hussain M, Ahmad A. Morbidity and mortality associated with Plasmodium vivax and Plasmodium falciparum infection in a tertiary care kidney hospital. Saudi J Kidney Dis Transpl. 2015;26:1169-76.

6. Mohapatra MK, Dash PC, Mohapatro SC, Mishra RN. Delayed gastric emptying time in adult cerebral falciparum malaria. J Vector Borne Dis. 2012;49:230-3.

7. Romero A, Matos C, González MM, Nuñez N, Bermudez L, de Castro G. Change in gastric mucosa in acute malaria. Genet Eng Biotechnol N. 1993; 47:123-8.

8. Wilairatana P, Meddings JB, Ho M, Vannaphan S, Looareesuwan S. Increased gastrointestinal permeability in patients with Plasmodium falciparum malaria. Clin Infect Dis. 1997;24:430-5.

9. Vincke IH, Lips M. Un nouveau Plasmodium d'un rongeur sauvage du Congo (Plasmodium berghei n. sp.). Ann Soc Belg Med Trop. 1948;28:97-104.

10. Yañez DM, Batchelder J, van der Heyde HC, Manning DD, Weidanz WP. Gamma delta T-cell function in pathogenesis of cerebral malaria in mice infected with Plasmodium berghei ANKA. Infect Immun. 1999;67:446-8.

11. Griffith JW, O'Connor C, Bernard K, Town T, Goldstein DR, Bucala R. Toll-like receptor modulation of murine cerebral malaria is dependent on the genetic background of the host. J Infect Dis. 2007;196:1553-64.

12. Penet MF, Viola A, Confort-Gouny S, Le Fur Y, Duhamel G, Kober F, et al. Imaging experimental cerebral malaria in vivo: significant role of ischemic brain oedema. J Neurosci. 2005;25:7352-8.

13. Taniguchi T, Miyauchi E, Nakamura S, Hirai M, Suzue K, Imai T, et al. Plasmodium berghei ANKA causes intestinal malaria associated with dysbiosis. Sci Rep. 2015;5:15699.

14. Matsuoka H, Yoshida S, Hirai M, Ishii A. A rodent malaria, Plasmodium berghei, is experimentally transmitted to mice merely probing of infective mosquito, Anopheles stephensi. Parasitol Int. 2002;51:17-23.

15. De Souza B, Helmby H. Concurrent gastro-intestinal nematode infection does not alter the development of experimental cerebral malaria. Microb Infect. 2008;10:916-21.

16. Mordmüller B, Supan C, Sim KL, Gómez-Pérez GP, Ospina Salazar CL, Held J, et al. Direct venous inoculation of Plasmodium falciparum sporozoites for controlled human malaria infection: a dose-finding trial in two centres. Malar J. 2015;14:117.

17. Sharp CR, Rozanski EA. Cardiovascular and systemic effects of gastric dilatation and volvulus in dogs. Top Companion Anim Med. 2014;29:67-70.

18. Van Kruiningen HJ, Gargamelli C, Havier J, Frueh S, Jin L, Suib S. Stomach gas analysis in canine acute gastric dilatation with volvulus. J Vet Intern Med. 2013;27:1260-1.

19. Turan M, Sen M, Canbay E, Karadayi K, Yildiz E. Gastric necrosis and perforation caused by acute gastric dilatation: report of a case. Surg Today. 2003;33:302-4.

20. Watanabe S, Terazawa K, Asari M, Matsubara K, Shiono H, Shimizu K. An autopsy case of sudden death due to acute gastric dilatation without rupture. Forensic Sci Int. 2008;180:e6-10.

21. Abdelwahab SI, Mohan S, Abdulla MA, Sukari MA, Abdul AB, Taha MM, et al. The methanolic extract of Boesenbergia rotunda (L.) Mansf. and its major compound pinostrobin induces anti-ulcerogenic property in vivo: possible involvement of indirect antioxidant action. J Ethnopharmacol. 2011;137:963-70.

22. Ibrahim MM, Ali HM, Abdullah MA, Hassandarvish P. Acute toxicity and gastroprotective effect of the Schiff base ligand $1 \mathrm{H}$-indole-3-methylene-5nitrosalicylaldimine and its nickel (II) complex on ethanol induced gastric lesions in rats. Molecules. 2012:17:12449-59.

23. Deplancke B, Gaskins HR. Microbial modulation of innate defense: goblet cells and the intestinal mucus layer. Am J Clin Nutr. 2001:73:1131S-41S.

24. Matsuoka H, Paton MG, Barker GC, Alejo Blanco AR, Sinden RE. Studies on the immunogenicity of a recombinant ookinete surface antigen Pbs21 from Plasmodium berghei expressed in Escherichia coli. Parasite Immunol. 1994:16:27-34.

25. Matsuoka H, Tomita H, Hattori R, Arai M, Hirai M. Visualization of malaria parasites in the skin using the luciferase transgenic parasite, Plasmodium berghei. Trop Med Health. 2015:43:53-61.

26. Kanda Y. Investigation of the freely available easy-to-use software 'EZR' for medical statistics. Bone Marrow Transplant. 2013:48:452-8.

\section{Ready to submit your research? Choose BMC and benefit from:}

- fast, convenient online submission

- thorough peer review by experienced researchers in your field

- rapid publication on acceptance

- support for research data, including large and complex data types

- gold Open Access which fosters wider collaboration and increased citations

- maximum visibility for your research: over $100 \mathrm{M}$ website views per year

At BMC, research is always in progress.

Learn more biomedcentral.com/submissions 